\title{
Protein E7, Human Papillomavirus Type
} 16

National Cancer Institute

\section{Source}

National Cancer Institute. Protein E7, Human Papillomavirus Type 16. NCI Thesaurus.

Code C1179.

Protein E7 (98 aa, $11 \mathrm{kDa}$ ) is encoded by the human papillomavirus type $16 \mathrm{E7}$ gene.

This protein is involved in the modulation of the activity of both retinoblastoma protein and histone deacetylases in the infected host cell, which is associated with viral genome replication and host cell transformation. 